human right due to its prevalence rate, involves other fundamental rights protection (right to life, information, liberty and security of a person, freedom of speech and thought, etc.), including implementation of the new generation rights - the right to anonymity and the right to be forgotten. The rights of people who are offline must also be protected on the Internet, which is recognized as a driving force for progress. The right to privacy as the right to live one's personal life with minimal outside interference not only from the authorities (the state), but also from similar actions by others. In international law, cyberbullying is recognized as a negative phenomenon, a form of domestic violence with using modern gadgets. The domestic legislator recognized bullying (acts of bullying) as acts consisting of psychological, physical, economic, sexual violence, including the using of electronic communications, committed against juveniles and minor or such a person against other participants in the educational process, as a result of which it could be whether the victim's mental or physical health was harmed. In the context of the rapid total digital transformation of society, the number of cases of online violence will only increase. And national law enforcement agencies should take this phenomenon seriously.

Key words: international low, right to privacy, cyberbullying, human rights and freedoms, theory of state and law, modern rights.

УДК 340.12

DOI https://doi.org/10.32782/2409-4544/2020-1/3

Ю. Крисюк

\title{
Дихотомія свободи та рівності як детермінуюча засада права
}

У статті досліджуються категорії свободи і рівності, їх спільність і відмінності, взаємозв'язок і взаємодія. Відзначається, що співвідношення свободи і рівності, враховуючи їх функціональні протиріччя, становить принципову проблему в тематиці змісту фундаментальних цінностей громадського співіснування в цілому і права зокрема. Відзначається, що свобода є насамперед правом на нерівність, оскільки рівність завжди $є$ посяганням на свободу. У дихотомії свободи і рівності ключову роль для суспільства відіграє третій елемент «конструкції права»- справедливість. Саме правова справедливість в кінцевому підсумку є дотриманням загального балансу, еквівалентності взаємних прав і обов'язків, якими пов'язані один з одним суб'єкти права. Таким чином, свобода, рівність і справедливість утворюють три вершини трикутника, який лежить в основі соціального інституту права. I жодну з них не можна порушити чи обмежити без шкоди для двох інших. Свобода кожної окремої людини закінчується там, де починається свобода іншої. Отже, тут неминуче застосування принципу рівності: свобода повинна бути рівною для всіх або ж iї не буде зовсім. Тому право виступає мірою свободи індивіда, воно вказує іiі рамки, межі, вихід за які порушує свободу іншого, а, отже, підриває правопорядок. Свобода, і рівність, і справедливість вкорінені, вписані в саму соціальну реальність і мають суто об'єктивне значення. Саме вони становлять сутність права, яка вимагає відповідно суб'єктивно-вольового оформлення у вигляді законів, указів і інших нормативних актів. Не примусова сила закону створює рівність, свободу і т. п., а, навпаки, об'єктивний принцип рівності проявляється (або не проявляється) в тому чи іншому законі. Перш, ніж бути зафіксованими формально, свобода і рівність повинні бути присутніми в соціальній реальності об'єктивно, як соціальна якість самої дійсності, а не просто як благі побажання законодавців.

Ключові слова: право, рівність, свобода, справедливість, суспільство.

Постановка наукової проблеми та її значення. Існує безліч уявлень про те, що таке свобода, як забезпечується рівність між індивідами та у чому має полягати соціальна справедливість, яка $\epsilon$ своєрідним висновком, котрий отриманий в результаті розмірковувань про свободу і рівність. Співвідношення свободи й рівності, 3 огляду на їх функціональні суперечливості, становить

○ Крисюк Ю., 2020 
принципову проблему в тематиці змісту фундаментальних цінностей суспільного співіснування загалом та права зокрема. Питання про співвідношення і пріоритети всередині двоєдності свободи й рівності сьогодні містить суперечності та продовжує дебатуватися, виявляючись у їхній дихотомії.

Аналіз досліджень цієї проблеми.Дослідженню категорій свободи та рівності приділяло увагу чимало видатних науковців, які $\epsilon$ представниками різних наук. Серед них С. С. Алексєєв, О. О. Бандура, Ф. Бекон, М. Бердяєв, Ф. Гаєк, Г. В. Ф. Гегель, Р. Дворкін, Л. Дюгі, I. Кант, Д. А. Керімов, А. А. Козловський, М. І. Козюбра, М. В. Костицький, Б. Леоні, О. А. Лукашева, С. І. Максимов, М. І. Матузов, В. С. Нерсесянц, К. Поппер, П. М. Рабінович, С. С. Сливка, Б. Спіноза, А. Токвіль, Х. Харт, В. О. Четвернін, В. В. Шкода, К. Ясперс та інші.

Формулювання мети статті. Метою нашого дослідження вважаємо системний аналіз співвідношення і пріоритетів у дихотомії правових засад свободи й рівності через призму філософсько-правових вчень, сучасних суспільних явищ.

Виклад основного матеріалу й обгрунтування отриманих результатів дослідження. Проблема свободи є однією 3 тих проблем, які зачіпають кожного і які неодмінно викликають суперечки. «У всіх суперечливих прагненнях нашого часу, - пише Карл Ясперс, - $€$ ніби одна вимога, яка об'єднує всіх. Всі народи, всі люди, представники всіх політичних режимів одностайно вимагають свободи. Однак в розумінні того, що є свобода і що робить можливим ії реалізацію, всі відразу ж розходяться. Можливо, найглибші протиріччя між людьми обумовлені їх розумінням свободи» $[1 ;$ с. 22]. Те, що одним здається шляхом до свободи, констатує Ясперс, інші вважають прямо протилежним цьому. Заради свободи відбувається майже все, до чого прагнуть люди. В ім'я свободи вони стають навіть на шлях рабства, при цьому можливість шляхом вільного рішення відмовитися від свободи виявляється іноді найвищою свободою. «Свобода породжує ентузіазм, але свобода породжує і страх. Інколи навіть складається враження, що люди зовсім не хочуть свободи, більше того, прагнуть уникнути самої можливості свободи» [1; с. 23].

Отже, що ж слід розуміти під свободою?

У філософських словниках свобода визначена як можливість прояву суб'єктом своєї волі на основі усвідомлення законів розвитку природи і суспільства. До того ж «свобода» - одна з основних філософських категорій, що характеризує сутність людини. Головне для людини - це свобода, яка має бути середовищем iї існування. У сфері свободи вона вибирає власний життєвий шлях, реалізує інтереси та бажання. Тільки розуміння свободи як потенційної здатності людини до вільного вибору альтернативи, як можливості мислити і вчиняти відповідно до своїх уявлень, бажань, а не як наслідок внутрішнього або зовнішнього примусу, дає особистості можливість знайти духовну свободу та людині - саму себе.

Для «західної» думки традиційним було та в певній мірі залишається й зараз негативне трактування поняття свободи. Як приклад наведемо визначення чеського правника Зденека Нойбауера: «Свобода за своєю суттю поняття негативне, - воно означає негацію (відсутність) будьяких обмежень, примусів, тисків, повинностей, обов'язків..., саме того, що є основою держави.

Отже цілком зрозуміло, що держава з абсолютною свободою немислима. У політичній теорії та практиці мова може йти тільки про відносну свободу» [2; с. 27]. Екзистенціальне розуміння свободи людини, характерне для французької політології, також призводить в кінцевому результаті до негативного розуміння свободи. 3 урахуванням того, що філософія екзистенціалізму вважає необмежену свободу внутрішньо притаманною людині, для неї неприйнятне будь-яке позитивне формулювання свободи. Державі відводиться лише завдання усунення перепон, що перешкоджають реалізації останньої.

Цікаву з філософської точки зору конструкцію поняття свободи особистості, що базується на індивідуалістичній основі, запропонував англійський політолог Джон Лукас. На його думку, поняття свободи повинно містити як позитивну сторону, так і негативну, причому обидві сторони - як свобода «робити будь-що», так і свобода «від будь-чого» - знаходяться в тісному взаємозв' язку. Позитивна свобода - свобода «робити будь-що» - завжди має на увазі здатність-можливість суб'єкта до цієї діяльності [3; с. 122].

Наукове поняття свободи особистості сформулював Фрідріх Енгельс, який стверджував, що не в уявній незалежності від законів природи полягає свобода, а в пізнанні цих законів і в заснованій на цьому знанні можливості планомірно змушувати закони природи діяти для певних цілей. Ця теза проникнута оптимістичним гуманізмом, вірою в нескінченність процесу пізнання і можливостей людини по перетворенню навколишнього світу на основі самого процесу пізнання, що постійно поглиблюється. Енгельс пов'язує розширення свободи з розвитком процесу пізнання [4, с. 99-100].

Сформований в XIX ст. консерватизм, як і лібералізм, відстоює індивідуалістичну свободу, хоча трактує їі інакше. Лібералізм тлумачить свободу як право особистості чинити згідно власній волі і в першу чергу як можливість користуватися невід'ємними правами людини; свобода індивіда обмежується лише аналогічною свободою інших людей. Логічним доповненням такої свободи $\epsilon$ 
політична рівність усіх людей, без якої свобода не має сенсу. Лібералізм практично ніколи не вимагав повної рівності. Однак, консервативна думка приписала йому, твердження, що люди фактично з усіх точок зору рівні. На противагу цьому положенню було висунуто нове тлумачення свободи. Стверджується, що люди принципово нерівні, нерівні талантом і здібностями, нерівні в самій своїй сутності. Таким чином свобода може грунтуватися виключно на здатності кожного індивіда розвиватися без перешкод з боку інших згідно з правом і вимогами власної особистості.

Видатний німецький юрист та філософ Фрідріх Шталь стверджував, що «свобода полягає не в здатності діяти так чи інакше, виходячи з власних довільних рішень. Свобода полягає в здатності зберегти себе і жити у відповідності з найглибшою сутністю власної особистості. Найглибша сутність людини - це індивідуальність, яка не визнає ніяких зовнішніх законів і розпоряджень. Проте ті права людини, які захищають незалежну приватну сферу, а також визнають за нею право брати участь в політиці держави, складають суттєвий елемент політичної волі. Мета політики - забезпечити матеріальну, а не тільки формальну свободу. Вона не повинна відокремлювати людину від фізичної влади або морального авторитету та історичної традиції держави, щоб не засновувати держави на звичайній індивідуальній волі. Найбільш глибока сутність людської особистості - це не тільки індивідуальність, але і мораль...» [5, с. 5-6]. Консерватизм підкреслює особливе значення так званих органічних колективних цінностей (передусім моралі й держави).

В індивідуалістичних суспільствах автономія особистості і відповідні свободи й права людини $€$ однією 3 домінант та одним 3 найбільш важливих показників рівня розвитку суспільства. У колективістських суспільствах особистість без залишку розчиняється в різних колективних цінностях, характерних для даних суспільств, і питання про свободу суверенної особистості сприймається як прямий замах на самі основи суспільства. Індивідуалізм передбачає вільну особистість, колективізм їі виключає.

У розвитку демократичного суспільства бувають такі кризові періоди, коли більшість його членів виявляються готовими відмовитися від свободи в ім'я цінностей, які здавалися їм більш значущими. У спокійні, відносно благополучні періоди багато індивідів цього суспільства теж не в захваті від своєї свободи. Свобода - це також відповідальність за прийняті рішення і боротьба за їх реалізацію. Багатьом не хотілося б постійно боротися за своє місце під сонцем. Замість щоденної та часом жорстокої боротьби за існування вони надали б перевагу менш комфортному, але спокійному і позбавленому елементів боротьби та ризику життю. Вони вважають, що той, хто хоче отримати від життя багато, нехай випробовує долю. Але ті, хто готовий задовольнятися тим невеликим, що не принижує їх гідність, мають право жити спокійно і не займати себе постійними роздумами про те, що буде завтра, як складуться обставини, котрі мало залежать від їхньої волі, та до яких результатів приведуть щойно прийняті на власний страх і ризик (вільні) рішення. Багато людей схильні ставити безпеку і стійкість свого становища вище індивідуальної свободи, котра завжди передбачає відповідальність і ризик.

Один з найвидатніших філософів ХХ ст. Микола Бердяєв стверджував: «воістину, у свободі $є$ скоріше щось аристократичне, ніж демократичне. Це цінність, котра дорожча людській меншості, ніж людській більшості, звернена перш за все до особистості, до індивідуальності. Мрія про гармонійне поєднання свободи й рівності $є$ нездійсненна раціоналістична утопія. Ніколи не може бути примирення між домаганнями особистості і домаганнями суспільства, між волею до свободи і волею до рівності. Завжди буде зіткнення нестримного прагнення до свободи з нестримним прагненням до рівності. Жага рівності завжди буде найстрашнішою небезпекою для людської свободи. Воля до рівності буде повставати проти прав людини і проти прав Бога.

Свобода і рівність несумісні. Свобода $є$ передусім правом на нерівність. Рівність $є$ насамперед посяганням на свободу, обмеженням свободи. Свобода живої істоти, а не математичної точки, здійснюється в якісному розрізненні, у піднесенні, у праві збільшувати обсяг і цінність свого життя. Свобода пов'язана 3 якісним змістом життя. Рівність же спрямована проти будь-якого якісного розрізнення і якісного змісту життя, проти будь-якого права на піднесення. Свобода розковує нестримну волю до рівності і приховує в собі насіння самозаперечення та самознищення. Лібералізм породжує демократію і нестримно переходить в демократизм. Такий його послідовний розвиток. Але демократія нищить самі основи лібералізму, рівність пожирає свободу» [6; с. 148].

3 точки зору юриспруденції свобода - це закріплена в правовому акті можливість певної поведінки. Учення про свободу, що становить основу прав і свобод людини та громадянина, постійно розвивають філософи, політологи і юристи, які намагаються віднайти розумний баланс між свободою та рівністю, справедливістю і державним регулюванням.

Юридичне розуміння свободи як сутності людини та її існування полягає у можливості робити все, що прямо не заборонено законом і не шкодить іншим. Таким чином свобода у праві не може бути абсолютною. Вона завжди до певної міри обмежена, зокрема, рівним становищем інших людей. Звідси 
випливає, що сутність права становить собою рівну міру свободи індивідів, визначену законом, котра реалізується через суб'єктивні права.

Щодо проблеми рівності, то, як і у випадку зі свободою, існують різні підходи до ії розуміння. Зокрема iï розглядають як рівність можливостей (формальну рівність) або як рівність результатів (фактичну рівність). Ліберальна концепція передбачає лише формальну рівність, рівні можливості індивідів здійснювати свободу і власний вибір, а не зрівняльний розподіл благ. За такого підходу відмінності між людьми можуть бути пояснені тим, що люди різняться за своїми здібностями $\mathrm{i}$ талантами, а тому результат їхньої вільної діяльності різний. Крім того, якщо вираз «рівні можливості» розуміти буквально - як «однакові можливості» - то ця ідея просто нездійсненна. Одна дитина з'являється на світ у Сполучених Штатах, інша - в Індії, Китаї... Батьки однієї дитини, глибоко стурбовані ії добробутом в майбутньому, з дитячих років прищеплюють їй тягу до культури й освіти, а батьки іншої - легковажні і про майбутнє навіть не замислюються. Безумовно, від народження перед ними відкриті зовсім неоднакові можливості, і ці можливості жодним чином не можуть бути зрівняні [7; с. 69-99].

Однак ніякі довільно створювані перешкоди не повинні заважати людям досягти того положення в суспільстві, яке відповідає їх здібностям і до якого вони прагнуть, спонукувані своїми життєвими принципами. Відкриті перед людиною можливості повинні визначатися тільки іiі здібностями, а не походженням, національною приналежністю, кольором шкіри, релігією, статтю або іншими несуттєвими в даному випадку факторами.

Суспільство, яке ставить рівність (в сенсі рівності результатів) вище свободи, в результаті втратить і рівність, і свободу. Якщо заради досягнення рівності воно вдасться до сили, то це знищить свободу, а сила, застосована спочатку в ім'я найкращих цілей, виявиться в руках людей, що використовують іiі в своїх власних інтересах. На противагу цьому, суспільство, яке ставить свободу понад усе, знайде, навіть не ставлячи перед собою це завдання, і більшу свободу, і більшу рівність.

Ще один варіант зняття протиріч між свободою і рівністю пропонує Рональд Дворкін. Він виходить з протиставлення свободи і закону і вказує на те, що закони потрібні для захисту рівності і неминуче постають в якості компромісів щодо свободи. Тому він вважає, що спільного права на свободу, тобто права на свободу як таку не існує, є лише права на окремі свободи [8; с. 63].

Роберт Нозік пропонує поняття «рівність можливостей» та порівнює іiі зі змаганнями. «Змагання, де частина учасників стартувала ближче до лінії фінішу, - пише він, - не може вважатися справедливим, так само як і змагання, де частина учасників повинна нести якийсь вантаж або бігти 3 камінням в своєму взутті» [9; с. 3]. Таким чином, головним завданням стає забезпечення справедливих умов «змагання». Проте, на наш погляд, навіть якщо розуміти під рівністю рівні можливості, на практиці все одно навряд чи вдасться до кінця примирити принципи свободи і рівності. «Рівні можливості» - це лише ідеал, який може бути в більшій чи меншій мірі реалізований. Однак існує ряд факторів, що не залежать від волі людей, які роблять справжню рівність можливостей недосяжним.

Разом $з$ тим, слід мати на увазі, що існує безліч різних проявів свободи, і далеко не завжди вони протистоять принципу рівності. Також слід розмежовувати рівність і справедливість. Часто стверджують, що рівність особливо тісно прив'язана до справедливості, однак цей зв'язок порушується протилежною умовою про можливість кожного отримувати тільки заслужене незалежно від того, що одержує інший. Коли рівність повністю ототожнюють зі справедливістю, то її відносять не до конкретних, численних рівностей, а до фонового порядку, в якому окремі права, зі всією своєю мінливістю, рівно розподілені за заслугами, а тому справедливі. Тому протистояння свободи і рівності слід розглядати не як загальну проблему, а як сукупність протиріч між різними свободами і видами рівності, причому в кожному конфліктному випадку це протистояння має бути вирішене на користь того, що є справедливим в даній ситуації [9; с. 78].

Специфічну позицію розмежування свободи і рівності у праві відстоює Фрідріх Гаєк. Рівність загальних норм закону й поведінки $\epsilon$, напевно, єдиним видом рівності, який може вести до свободи і який можна гарантувати без знищення останньої. Свобода не тільки не може мати нічого спільного 3 будь-яким іншим видом рівності, а й призначена у багатьох випадках створювати нерівність. «Рівність перед законом була величною метою боротьби за свободу. Цю рівність, що підпорядковується нормам, які встановлює держава, можна просто доповнити такою ж рівністю норм, яким люди добровільно підкоряються у своїх взаєминах з іншими. Поширення принципів рівності на правила моральної та соціальної поведінки $\epsilon$ головним виразником того, що зазвичай називається демократичним духом, i, можливо, саме цей аспект згладжує нерівність, яку обов'язково породжує свобода» [10; с. 91].

Роман Лівшиц зауважив, що «... звичайно, і рівність, і свобода - суто правові ідеї. Та все ж, як ми вважаємо, найбільш повно й адекватно втілює сутність права ідея справедливості... Ця теза навряд чи може бути доведена логічними конструкціями. Вона має радше концептуальний характер. Право за своїм змістом, за своєю соціальною сутністю є засобом суспільної згоди, компромісу... Засобів 
суспільної згоди і компромісу в суспільстві може бути немало. Специфіка права як такого засобу розкривається в його формальному, інституційному визначенні. Право $є$ нормативно закріплена й реалізована справедливість» [11; с. 66]. Іншими словами, право $\epsilon$ нормативно закріплена справедливість, що полягає у реалізації суспільного компромісу.

Справедливість - це поняття про належне. Справедливість водночас не $\epsilon$ щось постійне, незмінне й універсальне, вона, як і добро, суперечлива, навіть антиномічна. Френсіс Бекон стверджував, що справедливість $є$ те, що об'єднує людей і створює підвалини для права [12; с. 247].

Свобода, рівність, справедливість... Може здатися, що в цих словах виражені лише якісь правові гасла, що вони можуть бути зафіксовані в якихось деклараціях-конституціях, а в реальному житті їх здійснення виявляється примарним. Такий погляд є досить поширеним. Однак у цьому випадку охоплюється лише зовнішня, поверхнева сторона справи.

Суть, яка прихована за цією зовнішньою видимістю, полягає в тому, що свобода, рівність і справедливість не вводяться законодавчо, не $\epsilon$ результатом свідомої процедури прийняття та виконання «хороших» законів, в які вони вписані. Навпаки, і свобода, і рівність, і справедливість вкорінені, вписані в саму соціальну реальність і мають суто об'єктивне значення. Саме вони становлять сутність права, яка вимагає відповідно суб'єктивно-вольового оформлення у вигляді законів, указів і інших нормативних актів. Не примусова сила закону створює рівність, свободу і т. п., a, навпаки, об'єктивний принцип рівності проявляється (або не проявляється) в тому чи іншому законі. Перш ніж бути зафіксованими формально, свобода і рівність повинні бути присутніми в соціальній реальності об'єктивно, як соціальна якість самої дійсності, а не просто як благі побажання законодавців.

На думку Гегеля, «підгрунтям права є загалом духовне, i його найближчим місцем та вихідною точкою - воля, яка вільна; так що свобода складає ії̈ субстанцію і сутність й система права є царство здійсненої свободи...» [13, с. 67].

Якщо мова йде про свободу, а не про привілеї, сваволю, деспотизм, то вона просто неможлива без принципу та норм рівності, без загального правила, єдиного масштабу й рівної міри свободи... Свобода не тільки не протилежна правовій рівності, а навпаки - виражається лише за допомогою рівності та втілена у рівності. Свобода і рівність невіддільні і взаємно припускають одна одну» [14; с. 26].

Висновки. Свобода кожної окремої людини закінчується там, де починається свобода іншої. Отже, тут неминуче застосування принципу рівності: свобода повинна бути рівною для всіх або ж ії не буде зовсім. Тому право виступає мірою свободи індивіда, воно вказує іiі рамки, межі, вихід за які порушує свободу іншого, а, отже, підриває правопорядок.

Здійснення ж правових принципів свободи і рівності відповідає за змістом третьому правовому началу - справедливості. Саме правова справедливість в кінцевому результаті є дотримання загального балансу, еквівалентності взаємних прав та обов'язків, якими пов'язані один з одним суб'єкти права. Таким чином, свобода, рівність та справедливість утворюють ніби три вершини трикутника, котрий лежить в основі соціального інституту права. I жодну 3 них не можна порушити/обмежити без шкоди для двох інших.

Свобода, і рівність, і справедливість вкорінені, вписані в саму соціальну реальність і мають суто об' єктивне значення. Саме вони становлять сутність права, яка вимагає відповідно суб' єктивновольового оформлення у вигляді законів, указів і інших нормативних актів. Не примусова сила закону створює рівність, свободу і т. П., а, навпаки, об’єктивний принцип рівності проявляється (або не проявляється) в тому чи іншому законі. Перш ніж бути зафіксованими формально, свобода і рівність повинні бути присутніми в соціальній реальності об’єктивно, як соціальна якість самої дійсності, а не просто як благі побажання законодавців.

\section{Джерела та література}

1. Ясперс К. Смысл и назначение истории / К. Ясперс/ - М.: Политиздат, 1991. - 527 с.

2. Neubauer Zdenek. Statoveda a theorie politiky / Zdenek Neubauer. - Praga. 1947. - 488 str.

3. Lucas J. R. Democracy and Participation Harmondsworth / J. R. Lucas. - Penguin. 1976. - 290 p.

4. Благож Йозеф. Формы правления и права человека в буржуазных государствах: [Пер. с чеш.] / Йозеф Благож; С предисл. и под общ. ред. В. А. Туманова. - М.: Юрид. лит., 1985. - 222 с.

5. Stall F. J. Die gegenwärtigen Parteien in Staat und Kirche: neunundzwanzig akademische Vorlesungen (posthumous) / F. J. Stall. - Berlin, 1868. - $387 \mathrm{~s}$.

6. Бердяев Н. А. Философия неравенства / Н. А. Бердяєв; [состав., предисл. и примеч. Л. В. Полякова]. - М.: Има-пресс, 1990. - 288 с.

7. Фридман и Хайек о свободе: /[пер. с англ. под ред. А. Бабича]. - Репр. изд. Под общ. ред. 
Г. С. Лисичкина. - Минск: Полифакт-Референдум, 1990. - 126 с.

8. Dworkin R. Taking Rights Seriously / R. Dworkin. - Cambridge (Massachusetts): Harvard University Press, 1977 - 293 p.

9. Noziek R. Anarchy, State and Utopia / R. Noziek. - New York, 1974. - 442 p.

10. Гаєк Ф. А. Конституція свободи / Ф. А. Гаєк; [пер. 3 англ. М. Олійник, А. Королишин]. - Л.: Літопис, 2002. - $556 \mathrm{c.}$

11. Лившиц Р. З. Теория права: [учеб.] / Р. З. Лившиц. - М.: БЕК, 1994. - 210 с.

12. Бэкон Ф. Сочинения: в 2 т. /Фрэнсис Бэкон; [перевод., сост., общ. ред и вступ. статья А. Л. Субботина]. - Т. 1. - М.: Мысль, 1971. - 588 с.

13. Гегель Г. В. Ф. Философия права. Пер. с нем.: / Г. В. Ф. Гегель. Ред. и сост. Д. А. Керимов и В. С. Нерсесянц; Авт. вступ. ст. и примеч. В. С. Нерсесянц. М.: Мысль, 1990. - 524 с.

14. Нерсесянц В. С. Философия права: [учеб. для вузов] / В. С. Нерсесянц. - М.: Изд. группа «ИНФРАM - HOPMA», 1997. - 652 c.

Крысюк Ю. Дихотомия свободы и равенства как детерминирующая основа права. В статье исследуются категории свободы и равенства, их общность и различия, взаимосвязь и взаимодействие. Отмечается, что соотношение свободы и равенства, учитывая их функциональные противоречия, составляет принципиальную проблему в тематике содержания фундаментальных ценностей общественного сосуществования в целом и права в частности. Отмечается, что свобода является прежде всего правом на неравенство, поскольку равенство всегда посягает на свободу. В дихотомии свободы и равенства ключевую роль для общества играет третий элемент «конструкции права» - справедливость. Именно правовая справедливость в конечном итоге является соблюдением общего баланса, эквивалентности взаимных прав и обязанностей, которыми связаны друг с другом субъекты права. Таким образом, свобода, равенство и справедливость образуют как бы три вершины треугольника, который лежит в основе социального института права. И ни одну из них нельзя нарушить/ограничить без ущерба для двух других. Свобода каждого отдельного человека заканчивается там, где начинается свобода другого. Здесь неизбежно применение принципа равенства: свобода должна быть равной для всех или ее не будет вовсе. Поэтому право выступает мерой свободы индивида, оно указывает ее рамки, границы, выход за которые нарушает свободу другого, а, следовательно, подрывает правопорядок. Свобода и равенство, справедливость, вписанные в саму социальную реальность, имеют сугубо объективное значение. Именно они составляют сущность права, которая требует соответственно субъективно-волевого оформления в виде законов, указов и других нормативных актов. Не принудительная сила закона создает равенство, свободу. А, наоборот, объективный принцип равенства проявляется (или не проявляется) в том или ином законе. Прежде, чем быть зафиксироваными формально, свобода и равенство должны присутствовать в социальной реальности объективно, как социальное качество самой действительности, а не просто как благие пожелания законодателей.

Ключевые слова: право, равенство, свобода, справедливость, общество.

Krysiuk Yu. Freedom and Equality Dichotomy as a Determining Postulate of Law. The article examines the categories of freedom and equality, their commonalities and differences, the relationship and interaction. The relationship between freedom and equality, given their functional contradictions, is a principal issue in the context of the fundamental values of social coexistence, in general, and law, in particular. It is emphasized that freedom is, first and foremost, a right to inequality since equality always contravenes freedom. In the dichotomy of freedom and equality, the third element of the "construction of law', justice, plays a principal role in society. The legal justice ultimately means observance of the general balance, the equivalence of mutual rights and obligations, by which the subjects of law are connected with each other. Thus, freedom, equality, and justice form, as if the three vertices of the triangle that underlies the social institution of law. And none of them can be violated or restricted without detriment to the other two. The freedom of each individual ends where the freedom of the other begins. Thus, the application of the principle of equality is inevitable: freedom must be equal for all or it will not be at all. Therefore, the law is a measure of individual freedom, it indicates its scope, limits, beyond which violates the freedom of another, and, consequently, undermines the rule of law. Freedom, and equality, and justice are rooted, inscribed in the very social reality, and have a purely objective meaning. They are the essence of the law, which requires, respectively, subjective and volitional registration in the form of laws, decrees and other regulations. It is not the coercive force of law that creates equality, freedom, etc., but, on the contrary, the objective principle of equality is manifested (or not manifested) in one or another law. Before being formally enshrined, freedom and equality must be present in social reality objectively, as a social quality of reality itself, and not simply as the good wishes of legislators.

Key words: law, equality, freedom, justice, society. 